研究

\title{
オーステナイト系ステンレス鋼粉の固相急速焼結
}

\author{
中村 満山1, 稲垣 孝的2, 李尚学的1 \\ 的 1 岩手大学工学部, 干 020-8551 盛岡市上田 4-3-5. \\ 的 2 岩手大学大学院, 干 020-8551 盛岡市上田 4-3-5.
}

\section{Rapid Solid Sintering of Austenite Type Stainless Steel Powders}

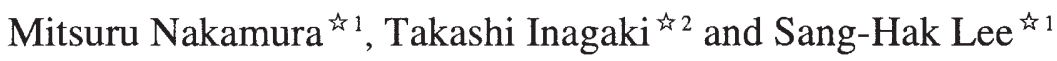 \\ 4ै 1 Fac. Eng., Iwate University, 4-3-5 Ueda, Morioka 020-8551, Japan. \\ ${ }^{2}{ }^{2}$ Graduate Student, Iwate University, 4-3-5 Ueda, Morioka 020-8551, Japan.
}

Received April 5, 2006

\section{SYNOPSIS}

Austenite type stainless steel powders (SUS304L) with rapid solid sintering were investigated by condition of heating rate $10 \mathrm{~K} / \mathrm{s}$ constant. The sintering was at a constant temperature of $1573 \mathrm{~K}$ and holding time changes from $60 \mathrm{~s}$ to $360 \mathrm{~s}$. The cooling methods were done by 2 different types: cool in $\mathrm{N}_{2}$ gas and furnace cool. Sintered specimens were evaluated on each mechanical property. As a result, radial crashing strength was obtained almost the same values when holding time is over $300 \mathrm{~s}$ compared with continuous furnace sintering condition. And, influence of cooling method (cool in $\mathrm{N}_{2}$ gas or furnace cool) was not observed. Dimensional change ratio gained good values compared by liquid sintering. The values were maxima as $1.5 \%$ contraction ratios for both outside and inside direction. In this experiment, rapid solid sintering was able to be finished only for $490 \mathrm{~s}$.

\section{KEY WORDS}

Rapid sintering, solid sintering, austenite type stainless steel, R.C.S., dimensional change

\section{1 緒言}

一般的な溶製材のオーステナイト系ステンレス鋼 (SUS304L) は耐食性, 耐熱性に優れ，機械構造用部品をはじ め建築用部材としても広く用いられている1)。しかし，この SUS304L 材を粉末冶金法による従来の固相焼結製品にする と, 材料中のポアが原因で高密度な焼結体が得られず, 強度, 耐食性とも溶製材に大きく劣っており，ステンレス鋼として の機能を充分に発揮できていないのが現状である. SUS304L 粉の焼結では，従前より液相焼結が一般的であった，液相焼 結は，焼結時に $\mathrm{B}, \mathrm{Si}$ 等を添加することによって，高緻密化， 密度の上昇, 高強度化及び耐食性が改善され, 引張強さにお いては溶製材とほぼ同等の強度を示すのに対し, 成形性の悪 化，大幅な寸法変化率(収縮)の増加が起こることが著者らに よって報告されている2). 結果として，焼結の際，液相を生 じることにより, 寸法変化率は等軸的な変化ではないため, 未だに溶製材の各種物性と比較すると大幅に劣っているのが 現状である。

最近，ニアネットシェイプの観点より，固相焼結が再度見
直されている，一方，著者らはこれまでに，近年注目されつ つある電磁エネルギー焼結法である誘導加熱を用い, 一般の 鉄系焼結機械部品の急速焼結を行ってきた. その結果, 誘導 加熱法による急速焼結は通常の連続炉と比較すると焼結時間 を約 $1 / 40$ も短縮することが可能であり，環境污染・省エネル ギ一対策としても有効で，工業的にも大きな効果が期待できる ことを示した ${ }^{3)}$. そこで，本研究では，オーステナイト系ス テンレス鋼粉の固相焼結を誘導加熱法による急速加熱で行い, ステンレス鋼粉の固相急速焼結の可能性について検討した.

\section{2 実験方法}

Fig.1 は本実験で用いた SUS304L 粉 (18Cr-8Ni-0.03C)の SEM写真を示す. 水アトマイズ法で製造されたため, 粉末形 状は凹凸のある不規則形状をしている。試験方形状は前報3) と同様に, 外径 $27.17 \mathrm{~mm}$, 内径 $15.98 \mathrm{~mm}$, 高さ $9.98 \mathrm{~mm}$ のリ ング状にした試験片を使用した。この形状は粉末冶金製品の ほとんどが中空製品であり，ギアや含油軸受が多いため，実 物とより近い形状とのことで用いた。 


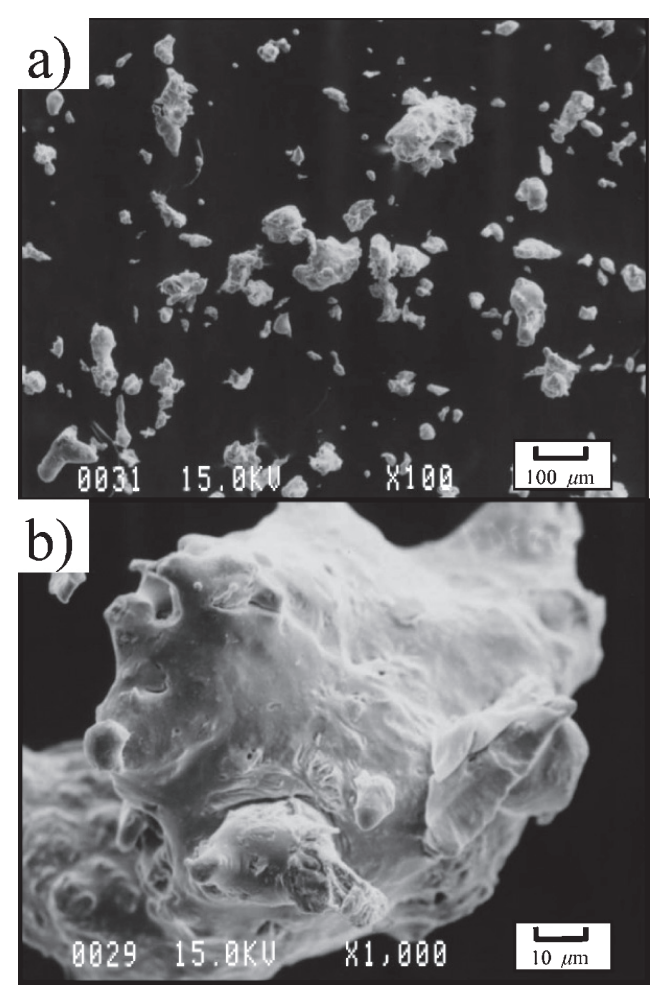

Fig.1 Shape of SUS304L powder used.

Sintering temperature: $1573 \mathrm{~K}$

Atmosphere: vacuum (13.3MPa)

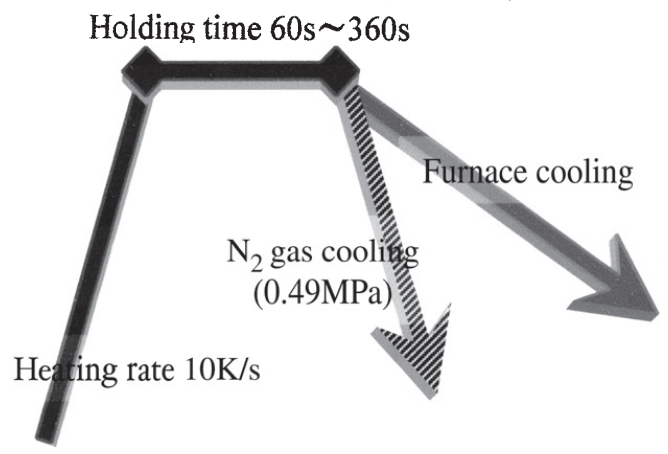

Fig.2 Schematic diagram of sintering treatment condition on SUS304L compacts.

誘導加熱は高周波加熱装置を用いており, THERMECMASTOR $\mathrm{Z}$ (富士電波工機製, PID 制御, PR 熱電対対応)により, 出力 $15 \mathrm{~kW}$, 周波数 $100 \mathrm{kHz}$ で $13.3 \mathrm{mPa}$ 程度の真空中で焼結をし た。本実験では，Fig.2に示すように，昇温速度 $10 \mathrm{~K} / \mathrm{s}$, 焼結 温度を $1573 \mathrm{~K}$ 一定とし，保持時間を $60 \mathrm{~s} \sim 360 \mathrm{~s}$ と変化させ た. 冷却は, ガス圧 $0.49 \mathrm{MPa}$ の $\mathrm{N}_{2}$ ガス冷却及び炉冷の 2 条件 で行った.

得られた焼結体は, 圧環強さ (Radial Crushing Strength), 焼 結密度, 寸法変化率の各測定, EPMA分析, X線回折及びビッ カース硬さ試験を行い，それぞれ評価した。

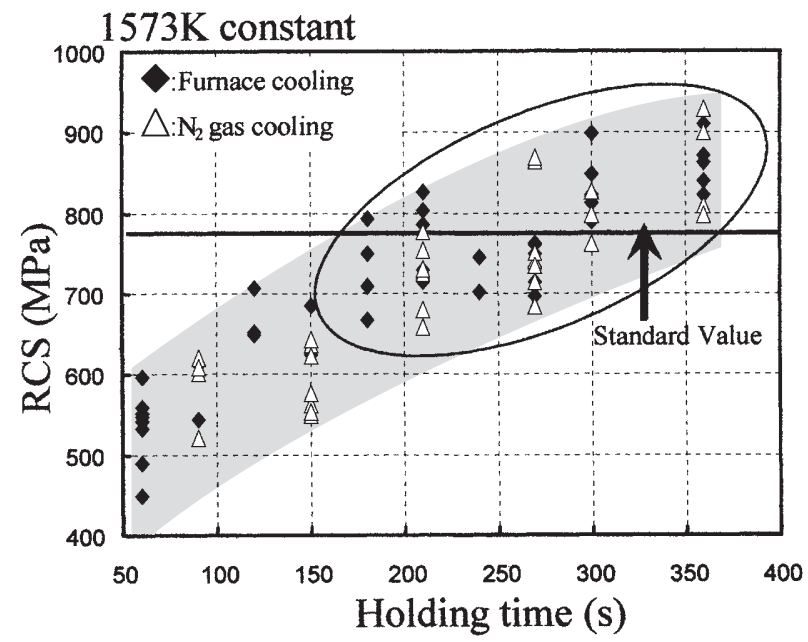

Fig.3 Relationship between holding time and RCS.

\section{3 実験結果および考察}

Fig. 3 は $1573 \mathrm{~K}$ での保持時間と压環強度 (RCS) の関係を示 す。炉冷及び $\mathrm{N}_{2}$ ガス冷却 $(0.49 \mathrm{MPa})$ ともに，180 s 以上保持 することによって，粒子それぞれの相互拡散が充分に進み， 通常炉の焼結とほぼ同程度の圧環強さ $(780 \mathrm{MPa})$ を得た。本 実験結果においては冷却方法による影響は少なく，ほぼ同一 の挙動を示していた. さらに, 保持時間が $300 \mathrm{~s}$ 以上の試料に おいては安定して高強度の試料を得ることができた。すなわ ち, 焼結時間を長くすることにより, 元素の拡散も充分でき ると考えられた。

Fig.4は外径方向, 内径方向それぞれの焼結保持時間と寸法 変化率の関係を示す. b) の内径方向に関しては, 保持時間に よりばらつく結果となったが，a)の外径方向は保持時間と共 に収縮が大きくなる傾向が見られた. 液相焼結においては液 相発生による緻密化に伴い寸法が大きく変化してしまう (約 10\%の収縮) のに比べ ${ }^{21}$, 本焼結法では成形時とほぼ同様の形 状を示し, 収縮率も最大 $1.5 \%$ 程度となり, 後加工での影響も 少ない良好な値であると考えられる。

Fig.5は焼結保持時間と焼結体密度の関係を示す. 保持時間 に比例して, 焼結体密度は上昇する結果となった。これは, 焼 結の進行によって粒子間のネックが成長し, 試料中に存在す るポアが減少していくため, 密度が上昇したと考えられる. 本実験結果でも, 炉冷と $\mathrm{N}_{2}$ ガス冷却による差は見られなかっ た。また, $360 \mathrm{~s}$ 保持試料においては, 最高で溶製材 $(8.02 \mathrm{Mg}$ ) $\mathrm{m}^{3}$ )の約 $80 \%$ の焼結密度となり, この密度の上昇によって強 度が上昇したと考えられた。

$\mathrm{N}_{2}$ ガスで冷却することにより, 試料極表面に $\mathrm{Cr}$ 窒化物の 存在が指摘されており ${ }^{4)}$, その窒化物の有無による物性值に 与える影響を検討した. Fig.6は $270 \mathrm{~s}$ 保持での冷却速度と圧 環強度の関係を示す．炉冷材においては冷却速度が約 $1.5 \mathrm{~K} / \mathrm{s}$ となっていたのに対し, $\mathrm{N}_{2} カ ゙ ス$ 冷却材においては約 $27 \mathrm{k} / \mathrm{s}$ と, 大きな速度の差はあるが強度には差が無く, 本実験において 


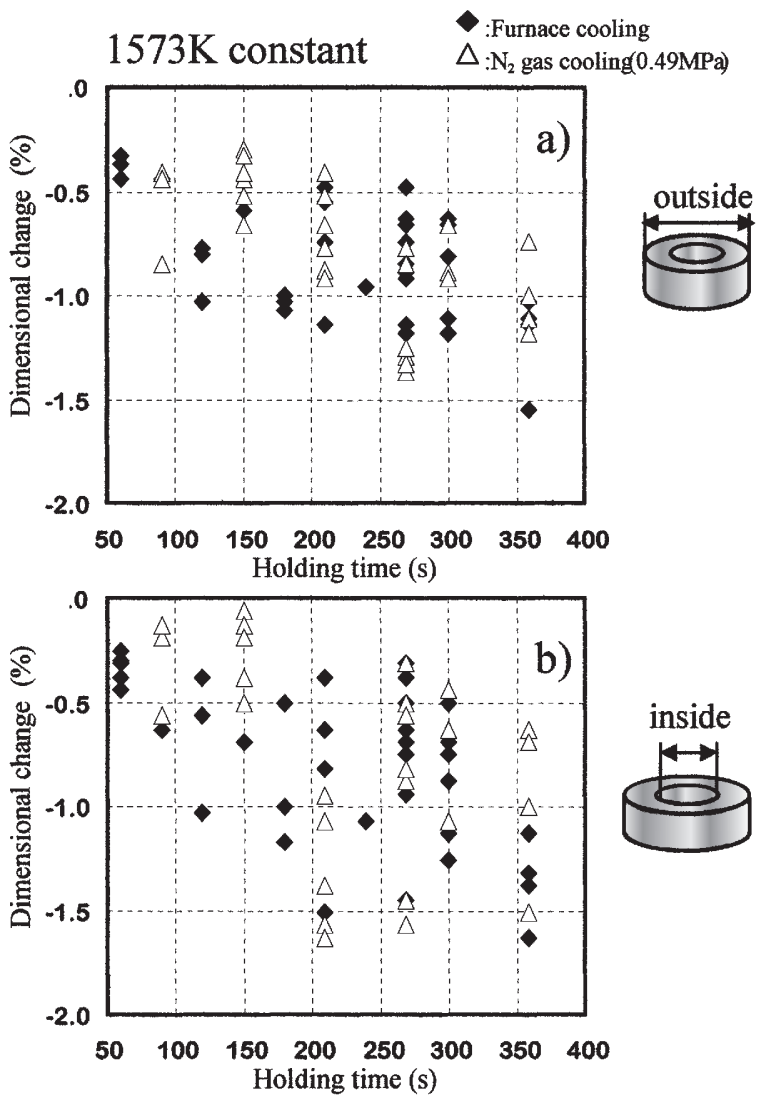

Fig.4 Relationship between holding time and dimensional change. (a): outside, (b): inside

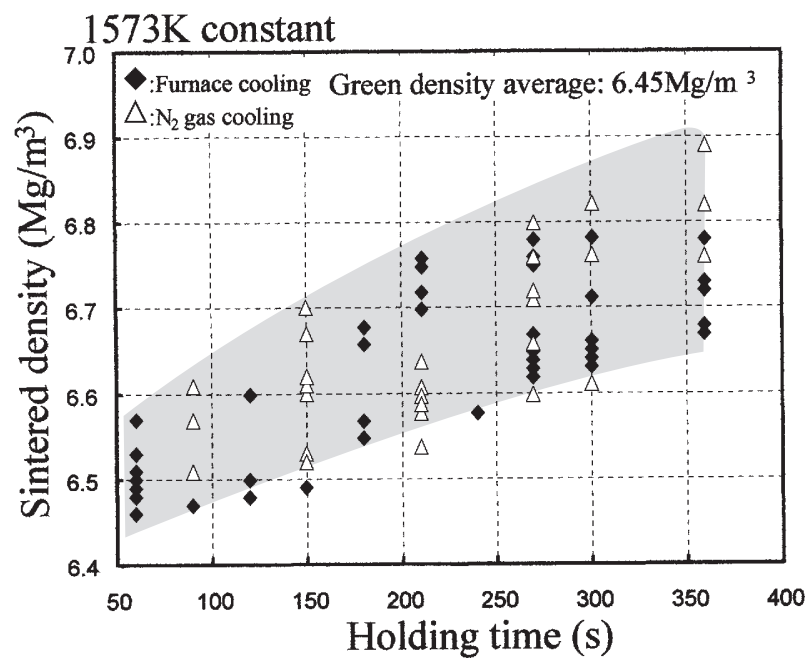

Fig.5 Relationship between holding time and sintered density.

は冷却方法による強度の影響はほとんど無いものと考えられ た.さらにEPMAで $\mathrm{Cr}$ 窒化物を調べたが, 本実験では存在が 確認できなかった。

Fig.7 は $270 \mathrm{~s}$ 保持試料の表面におけるXRD 分析結果であ る. 炉冷材及び $\mathrm{N}_{2}$ ガス冷却材ともにオーステナイト相がほと
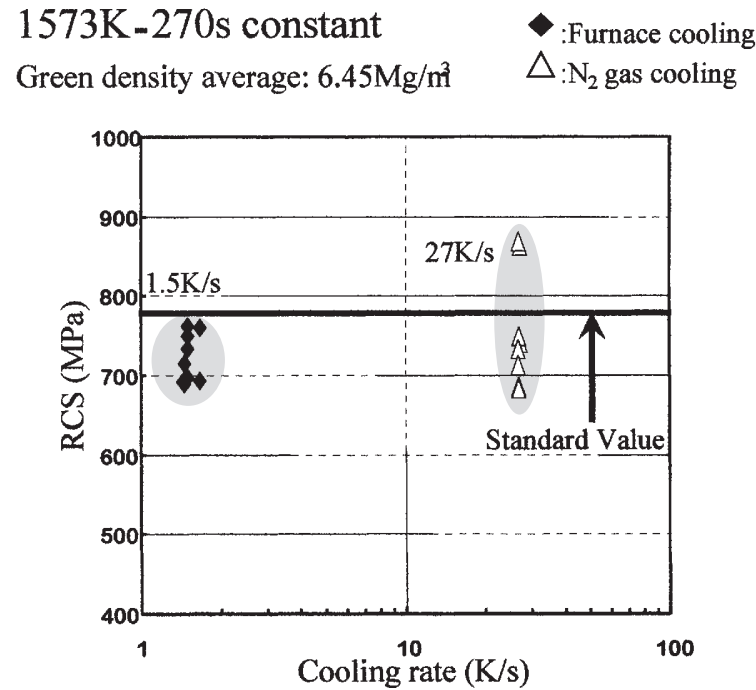

Fig.6 Relationship between cooling rate and RCS influenced by cooling conditions.

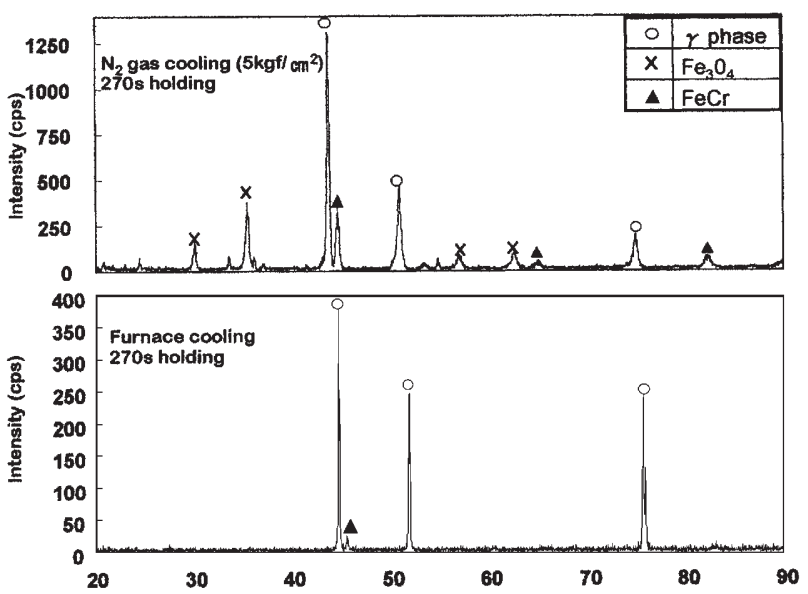

Fig.7 XRD analysis data of 2 types specimen.

んごで, $\mathrm{FeCr}$ も多少ではあるが同定された．また， $\mathrm{N}_{2}$ ガス冷 却材においてはFe酸化物も同定されたが, 窒化物は確認され なかった. 本実験では, 焼結炉の雾囲気は真空としているが, オーステナイト系ステンレス鋼は通常炉において $\mathrm{NH}_{3}$ 分解ガ ス中で焼結が行われることが多い. その場合, 焼結体表面が 窒化し強度は增すが，伸びは低下してしまう5). そして冷却 過程で窒化物 $\left(\mathrm{Cr}_{2} \mathrm{~N}\right)$ が析出することで耐食性が劣化してしま う. 本実験結果において窒化物は確認されなかったが, 真空 に比べ $\mathrm{NH}_{3}$ 分解ガスを使用するほうが取り扱いは容易であ り，またより経済的に焼結を行うために $\mathrm{NH}_{3}$ 分解ガス中での 焼結による影響についても今後検討していく必要があると考

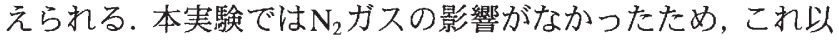
降炉冷材で保持時間の相違に注目して物性值を比較した.

Fig. 8 は $90 \mathrm{~s}$ 保持試料と $300 \mathrm{~s}$ 保持試料それぞれの圧環強度 試験後の破面写真である. $90 \mathrm{~s}$ 保持した試料は，一部に延性 


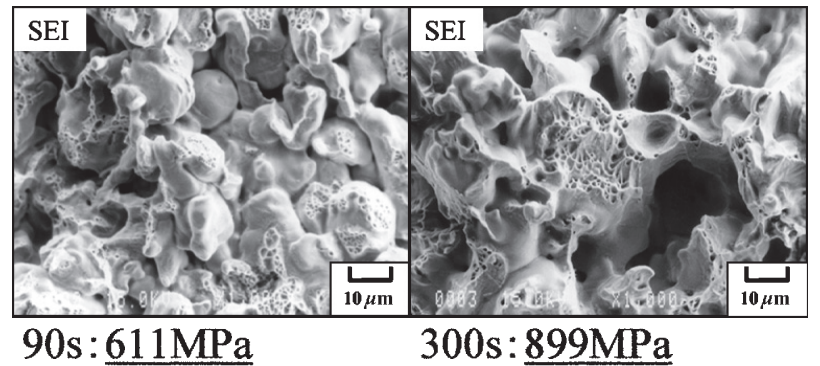

Fig. 8 Fractgraphs obtained by $1573 \mathrm{~K}$ treated specimen.

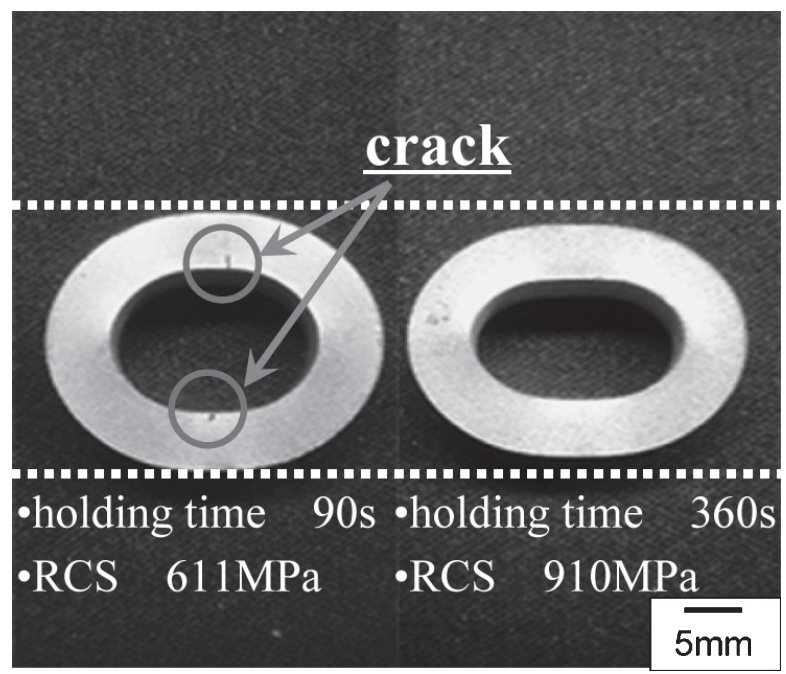

Fig.9 Photographs after RCS test at $1573 \mathrm{~K}$ sintering condition specimen.

破面であるディンプル (dimple) が確認されたが, その量は非 常に少なく，ほぼ粒子界面での破壊であった．また，写真か らも分かるように，破面には粉末粒子が単独で存在している 部分があり, 焼結による元素の拡散が不十分であることが分 かる. $300 \mathrm{~s}$ 保持した試料においては，90 s 保持した試料に比 ベ破面形態は大きく異なり，ディンプルも大きな部分から小 さな部分まで数多く確認された，また，単独で存在する粒子 も少なく,ネックが成長し焼結が進行していることが同える. 以上より，300 s 保持することによってネックの成長が進み, それによって密度が上昇, 焼結体の収縮が起こることが分 かった.

Fig.9 は圧環強度試験後の試料の外観写真である. $90 \mathrm{~s}$ 保持 した試料は変形が少なく,クラックが発生していることが分 かる. 一方，360 s 保持した試料は90 s 保持した試料に比べ大 きく変形しており,亀裂が発生しないものもあった.これは, 結合強度の上昇, さらに試料表面でのポアの減少によって, 延性が増加したために大きく変形したと考えられる。また， クラックの発生部分は外表面よりも内表面からが多く, この 原因として, SUS304L粉の熱伝導性が低いことにより均一に 焼結が進行しなかったこと, また誘導加熱法の特徵である表

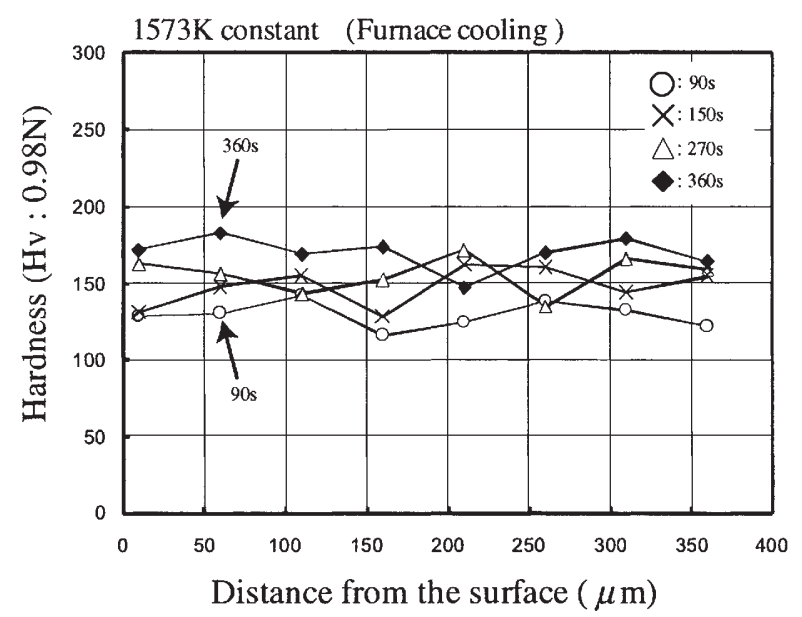

Fig.10 Result of Vickers hardness number test.

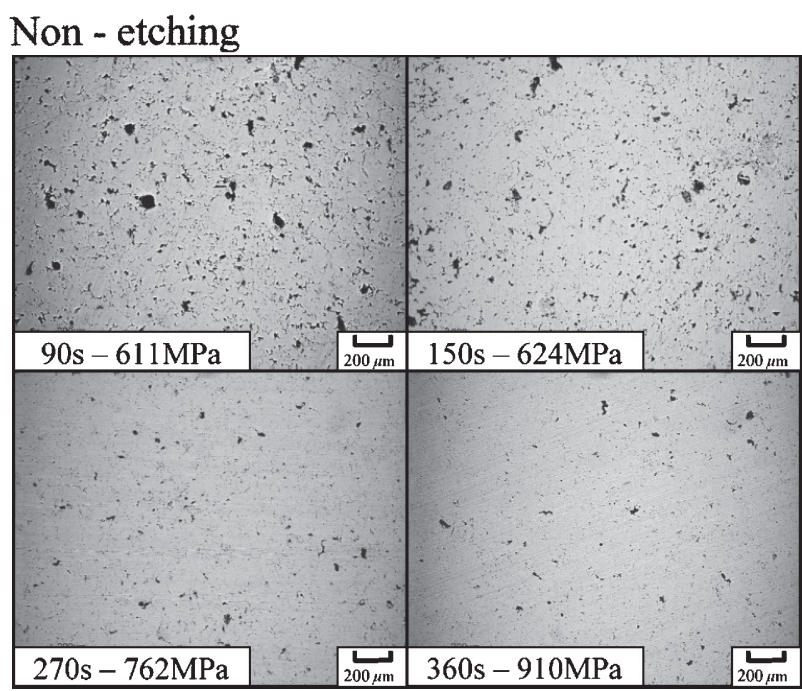

Fig.11 Optical micrographs of $1573 \mathrm{~K}$ treated specimens.

皮効果(skin effect) $)^{6}$ により試料内外でエネルギ一の差ができ, これにより試料内外での温度差ができたものと思われる.

Fig. 10 は $90 \mathrm{~s}, 150 \mathrm{~s}, 270 \mathrm{~s}$ 及び $360 \mathrm{~s}$ 保持試料それぞれの表 面近傍からのビッカース硬さ試験結果である.どの試料にお いてもほぼ同程度の硬さとなっていたが，やはり $90 \mathrm{~s}$ 保持試 料に比べ $360 \mathrm{~s}$ 保持試料の硬さが高くなつた.一般的な溶製材 のSUS304Lの硬さは約Hv220程度であり, 本実験結果は最高 でも約 Hv180 程度と溶製材の硬さに比べ低い結果となった. これは，組織によるものではなく，ポアによる影響であると 考えられる。

Fig.11 は各保持試料の光学顕微鏡組織写真である. 本実験 においては, SUS304L粉以外の粉末の添加は無く, 焼結後の 組織は一般的なオーステナイト系ステンレス鋼と同様であり, ポアの形状を確認するため腐食をせずに観察を行った. $90 \mathrm{~s}$, $150 \mathrm{~s}$ 保持試料においては, ポアが非常に多く, 焼結自体が不 


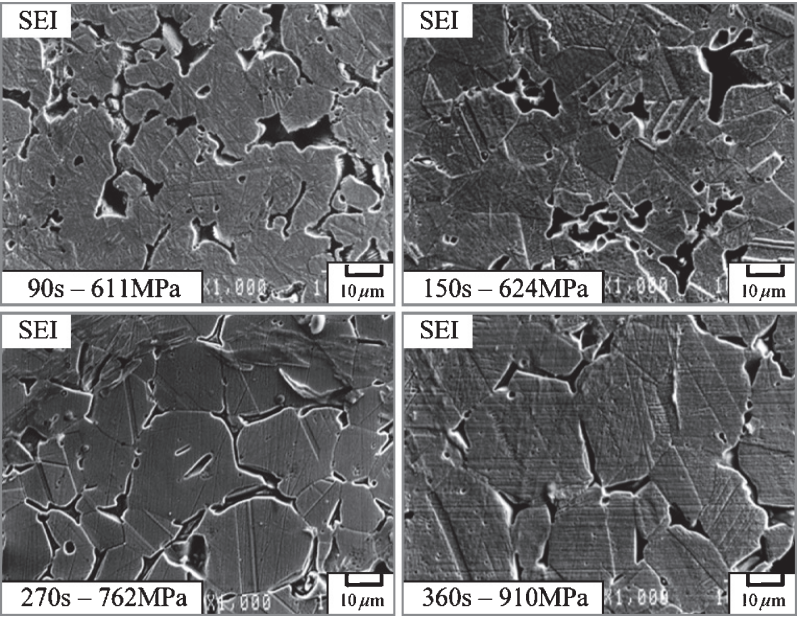

Fig.12 SEM micrographs of $1573 \mathrm{~K}$ treated specimens.

十分な状態であることが分かる.しかし， $210 \mathrm{~s}$ 保持以降の試 料ではポアの数が減少しており,このことからも密度が上昇 していることが分かる.

Fig.12 は同様に各保持試料の電子顕微鏡組織写真である. こちらの写真からも光学顕微鏡組織写真と同様に，保持時間 とともにポアが滅少している様子が確認できる，さらに，ポ アの形状もだんだんと丸みを帯びてきていることから，ポア による切り欠き効果も減少し，強度が向上したものと考えら れた。

本研究で用いた誘導加熱法は，一般の焼結法とは異なり， 被加熱物自体が加熱するため，急速燒結が可能であることが 示された。しかし，その焼結機構は一般的な固相焼結と同様 であり

初期段階…粒子相互のきわめてせまい部分での結合, すなわ ち拡散によるネックの生成と，ポアの減少.

中期段階... 粒界消失, 結晶成長などにより粒子の見分けがつ かなくなり,ポアも切り離され, 閉鎖ポアとなる. 終期段階... ポアは独立し, 数は減るが形が大きくなり残留. この3段階で焼結が進行》)していくものと考えられる. 昇温時 間も含め, 本実験結果においては約 8 分で焼結が完了し, こ れは一般の連続炉での焼結 (約 90 分) に比べ約 $1 / 11$ の大幅な 時間短縮となり,工業的に有益な焼結法であると考光られる.

\section{4 ま とめ}

オーステナイト系ステンレス鋼 (SUS304L) 粉を用い，寸法 変化率の改善，焼結時間の短縮及び強度の向上を目的に固相 急速焼結を行った結果，以下の結論を得た。
(1) 固相急速焼結においては，焼結温度 $1573 \mathrm{~K}$ 一定で 180 $360 \mathrm{~s}$ 保持することで, 元素の拡散が十分に進行し，一般 の通常炉での焼結における強度と同程度の圧環強さ (RCS) を得ることができた. また，保持時間 $300 \mathrm{~s}$ 以上の 試料においては安定して高強度の材料を得ることができ た.

（2）冷却方法についての検討を行った結果， $\mathrm{N}_{2}$ ガス冷却によ る表面組織変化はなく, 強度に関しても炉冷とほぼ同じ 挙動を示すことが分かった。

(3) 寸法変化率では, 外径, 内径方向ともに収縮率が最高で 約 $1.5 \%$ 程度となり, 液相焼結に比べ，良好な値を得るこ とができた。

（4）誘導加熱法を用いた場合の急速焼結は，一般的な固相焼 結と同じメカニズムで進行していき，保持時間を長くす ることによって, 焼結が進行し, ポアが減少することに よって，強度が上昇することが判明した。

(5) 以上の結果から, 本実験における最適条件は, 圧環強さ, 焼結体密度及び寸法変化率等を考慮した上で，昇温速度 $10 \mathrm{~K} / \mathrm{s}$, 焼結温度 $1573 \mathrm{~K}, 360 \mathrm{~s}$ 保持であり, 冷却において は炉冷が最適であった. すなわち, 昇温時間 $130 \mathrm{~s}$, 保持 時間 $360 \mathrm{~s}$ の計 $490 \mathrm{~s}$ (8 分 10 秒) で焼結が終了する急速加 熱が可能であった.

\section{文献}

1) Hasegawa et.al.: "Stainless Steel Handbook", Nikkan kogyo Press, (1973) 156-162.

2) M.Nakamura, K.Kamada, S.Hiratsuka and Y.Nomura: "Lowering of Liquid-phase Sintering Temperature and Improvement of Some Properties of P/M SUS304L Stainless Steels by the Addition of Silicon and Boron", J. Jpn. Soc. Powder Powder Metallurgy, 43(1996)1111-1116.

3) M.Nakamura, N.Chida, T.Ohba and Y.Sugaya: "Development of Rapid Sintering Technique on Carbon Steels by the Induction Heating Method", J. Jpn. Soc. Powder Powder Metallurgy, 46 (1999) 538-543.

4) S.Kusaka and T.Kato: "Some Improvement on Electro-magnetic Sintered Stainless Steels", Recent Progress in Iron Powder Metallurgy, ISIJ, (1996)26-31.

5) Y.Ishimaru: "Base and Application of Powder Metallurgy", Gijutsushoin, (1993)235-236.

6) Jpn. Heat Treatment Society: "Introduction of Metal Heat Treatment", Taigashuppan, (1974)63-64.

7) Y.Ishimaru: "Base and Application of Powder Metallurgy", Gijutsushoin, (1993)85-87. 